Visualizing the Lesbian in Contemporary India

\title{
Relighting the Fire: Visualizing the Lesbian in Contemporary India
}

\section{Churnjeet Mahn and Diane Watt}

Churnjeet Mahn, Lecture in English Literature at the University of Surrey, has research interests in women's travel writing, South Asian culture, postcolonial studies, and queer and gender studies.

Diane Watt, Professor of English and Head of the School of English and Languages at the University of Surrey, works on medieval literature, women's writing and gender and sexuality.

Dr Churnjeet Mahn, School of English and Languages, University of Surrey, Guildford GU2 7XH. Surrey, UK. 
Visualizing the Lesbian in Contemporary India

\section{Abstract}

This article revisits the controversy surrounding Deepa Mehta's Fire (1996), India's first publiclyreleased film depicting female same-sex desire. The film has become a touchstone for discussions of the representation of queer and LGBT lives in India. While the majority of critical accounts of the film have rejected the use of "lesbian" on the basis of its Anglo-American specificity, this article seeks to recast lesbians at the heart of Fire by filtering them through the lens of transnational protest, and by offering a close reading of the film's own play on religious and cultural symbolism. Viewed almost two decades after its release, in the light of the Delhi rape case of December 2012 and subsequent events, including the upholding of a law criminalizing gay sex in November 2013, the film now more than ever seems to offer a fantasy of the future, rather than a viable reality in the present day. Within Fire, the circumnavigation of heteronormative power and desire is certainly queer, but the film's labelling as "lesbian" subsequent to its release in India opened up an important public forum for a debate about female desire and independence that continues to resonate today. This article does not attempt to offer a conclusive argument about the use of the term "lesbian" to label the relationship between women that is depicted within the film, but it does examine the way in which the film itself visualizes desire between women, and in particular the use of Hindu narratives, imagery and motifs. The film's interpellation into lesbian politics is facilitated by the strong emphasis on a female-centred desire that is not defined by motherhood, that cannot be contained, and that demands to be seen.

Keywords: lesbian, India, Fire, film, Hindu 
"There is no word in our language to describe what we are or how we feel for each other".

\author{
Fire, Dir. Deepa Mehta
}

\title{
Introduction
}

Deepa Mehta's 1996 film, Fire has been discussed as a pivotal moment in Indian cinema for the visibility of queer lives. The film itself and the critical analyses that surround it connect the representation of intimate life between women in India with the interests and concerns of the Indian diaspora and with the problem of the colonial legacies in India that relate to issues of gender, sexuality and sexual identity. The film is centred around a middle-class Delhi family made up of Biji, a matriarch confined to the home, her two sons, Ashok and Jatin, and her two daughters-in-law, Sita and Radha. The family runs a video shop with an attached eatery. While Ashok represents traditional Indian values embodied in his devotion to a Hindu guru, his younger brother Jatin uses the video shop to rent out porn, and despite agreeing to an arranged marriage, he maintains a relationship with his Chinese-Indian girlfriend, Julie. As they work together in the close confines of the household and eatery, a sexual relationship emerges between the sisters-in-law under the watchful eye of their mother in law. The famous words cited above, which Sita utters to her lover Radha, have come to stand for both the insufficiency in the representation and realization of female same-sex desire in Indian culture and a critique of the imposition of Western sexual identities on Indian culture (see, for example, Bachmann 2002). Sita, as an educated middle-class woman, utters these words in English not Hindi. Whether the viewer is supposed to understand that Sita is unaware of the English word "lesbian" or that she does know the English term and is consciously rejecting it is unclear, and deliberately so. The issue of terminology, and the possibilities and constraints of languages, are central to the debate 
Visualizing the Lesbian in Contemporary India

in which the film is intervening. The term "lesbian" carries with it a weight of colonial history that the film, with its absence of reference points to female same-sex desire in Western culture, successfully sidesteps.

"Lesbian" is a term that many contemporary critics also choose to reject when discussing the film. Gayatri Gopinath and Jinga Desai, for example, have framed Fire in the context of queer rather than lesbian desire (Gopinath 2005; Desai 2002). Gopinath's use of queer is deployed "to refer to a range of dissident and non-heteronormative practices and desires that may very well be incommensurate with the identity categories 'gay' and 'lesbian'” (Gopinath 2005: 11). Although Fire was directed by an Indo-Canadian film-maker, and received funding in North America and India, its exclusively Indian setting has positioned it away from explicit discussions of how the Indian diaspora views or represents Indian sexualities. While it has been discussed extensively, the majority of work has concentrated on reading the way the film rejects Western identity categories and terminology at the same time as it represents as queer ideas of sexuality in a South Asian context. Paola Bacchetta, for example, argues that lesbian and gay are too historically located in Western culture to provide models that are transhistorically or transnationally viable (Bacchetta 1999: 144). Ruth Vanita's response is to point to the variety of terminology for female same-sex desire in Indian cultures, dating back to the sixth century B.C.E. (Vanita 2002: 2; for an alternative global approach, see Rupp 2011). By locating the film within an analysis of the long history of female same-sex desire, the erasure of intimate relationships between women in contemporary Indian culture becomes visible (see also Arondekar 2005 on the erasure of intimate lives from the colonial archive). Between the critical imperative to avoid exporting 
Visualizing the Lesbian in Contemporary India

identity-based labels from the West into South Asian contexts, and the emerging evidence of Indian genealogies for same-sex desire, the lesbian becomes a redundant figure. Or does she? Revisiting the film in 2013, in the light of the now notorious Delnhi rape case of December 2012, and focusing on representation of the sacred, the mother, kinship and desire, this article considers some of the ways in which the transnational lesbian may still prove a viable and vital figure in viewing Fire.

\section{The Transnational Indian Lesbian}

As Alexandra Lynne Barron has pointed out, the majority of the criticism on Fire focuses on its reception and the ways in which it troubles and destabilizes normative family values underpinned by Indian nationalism (Barron 2008). One of the most infamous comments on lesbian desire in the film comes from the North American film critic, Roger Ebert:

It is of course the Indian context that gives this innocent story its resonance. Lesbianism is so outside the experience of these Hindus, we learn, that their language even lacks a word for it. (Ebert 1997)

Ebert's assertion about the "innocence" of India is as unfounded as it is inappropriate. Bacchetta has offered an overview of the variety of female same-sex identified organizations in 1980s Delhi as a test case for the kinds of transnational queer subjects that were emerging in India's urban centres (Bacchetta 1999). India's first gay magazine, Bombay Dhost, was published in 1990, with the first high-profile protest in favour of gay rights happening in Delhi in 1992. Coverage from the 1992 protest includes banners with messages such as: "Gay Manifesto!! Gays 
Visualizing the Lesbian in Contemporary India

of the world unite. You have nothing to lose but your CHAINS!" (Pink Pages 2013). The urban centers of India in the 1990s were beginning to develop publically visible and organised networks of support and resistance under the banner of gay rights. At the same time, lesbian and gay identified scholarship began to focus on the longer history of homosexuality in India. In the same year that Fire was released Giti Thadani published Sakhyani: Lesbian Desire in Ancient and Modern India (Thadani 1996). Naisargi N Dave's work has traced the first appearance of "lesbian" in Indian print media to 1987 (Dave 2010) with a growing awareness in the media of LGBT issues. When conservative nationalists attacked screenings of Fire in 1997 for its depiction of apparently non-Indian sexuality, many of the protests against the violence were organised by LGBT-identified organizations. One of the placards that was captured by the media read: "Indian and Lesbian" (Dave 2011).

CALERI, the umbrella organization that was formed to react to the protests against the screening of Fire, made a deliberate choice to adopt the term "lesbian" in the film's defence, even though its director, Deepa Mehta, sought to distance herself from this label: "We did consider arguments that the word 'lesbian' is western and elitist, but we also felt that, in a campaign which is to take information to the people, we need to organize around a word whose meaning is unmistakable and direct' (quoted by Dave 2012: 157). This conscious and ideologically-motivated invocation reveals the mobilization of a strategic transnational lesbian identity whose visibility and viability is posed as a challenge to a narrowly defined Indian nationalist agenda. The lesbian becomes a figure to set light to a variety of same-sex experience in India. Contrary to the expectations that Mehta might be introducing non-Indian themes into a film set in India, Mehta's distancing from 
Visualizing the Lesbian in Contemporary India

the term "lesbian" and the identification and articulation of the term by grassroots organizations in India, speak to the importance of readdressing and rethinking the importance of the term for women in India. Although recent work in South Asian queer diaspora studies has created a critical distance from terms associated with historically and geographically specific terms such as "lesbian" in the context of India, it is possible to argue that there is a cleavage between the work of critics, who themselves belong to an educated Indian or diasporic elite, and the labelling of sexual practices and identities in urban India, where grassroots activism has consciously borrowed from a transnational nomenclature. While the critical turn in discussions of Fire has been away from the lesbian towards the queer, this article revaluates the lesbian in Fire as a figure that goes beyond an erroneous or neo-colonial imposition of Western politics and desire in a South Asian context.

\section{Sacred Femininity}

The key to the protests behind Fire was the apparent masquerading in saris of non-Indian sexuality in a middle-class Indian home. The violence surrounding the protests against the film was at once a defense of traditional Indian values by the Hindu right, and a reaffirmation of the sacred value of the mother and wife in the home, a role which was seen to be absolutely threatened and corrupted by the lesbian. Moving forward fifteen years to December 2012, there is another series of violent protests centered on the rights and behavior of women. From the protests that erupted in the wake of the brutal rape and murder of a student on a Delhi bus, to the wave of protests demonstrating against the government and police's reactions, the stories of rape and sexual abuse that emerged in the media picked at an intense contradiction in Indian values. 
Visualizing the Lesbian in Contemporary India

The incident points to the kinds of dangers posed to women who strayed beyond the protective limits of domesticity. Even though the victim was accompanied, it was not by a member of her family. When officials eventually elevated the attack to an attack on the nation, the victim was positioned as a daughter of the nation; a daughter that a mother would protect. As the nation urgently addresses legislation covering rape, other groups of women are becoming increasingly vulnerable. The repeal of Section 377 of the Indian Penal Code in 2009, which had criminalized same-sex relations, was a sign of changing attitudes to gays and lesbians in India. The overturning of this decision by India's Supreme Court in December 2013 is an indication of how fragile rights relating to gender and sexuality are in India.

Mother India, or Bharat Mata, has been are the forefront of Indian national imagery, drawing heavily from a variety of Indian mythologies and religions. In her study of the history and emergence of Mother India, Sumathi Ramaswamy has argued that the emergence of mother as nation was a product of colonial mapping. From the late colonial period, when Indian nationalism began to find a new voice, the mother-goddess represented the force that could give birth and nurture a new state that could overcome religious and ideological conflict (Ramaswamy 2010). Bollywood's seminal film, Mother India (1957), portrayed the ideal Indian mother: a selfless woman who would make any sacrifice for her family. Her self-reliance and response to adversity was a symbol for an India struggling to realise its own independence. As Ramaswamy has argued, "Despite the garb of venerable antiquity in which Bharat Mata has been presented to her (Indian) beholders, she is a tangled product of charged encounters between the 
Visualizing the Lesbian in Contemporary India

new and the old and of a fraught and conflicted modernity that is Indian's late colonial and postcolonial experience of history" (Ramaswamy 2010: 2).

When the President of India spoke after the death of the Delhi student, he spoke of the victim as a daughter of the nation: "She was a brave and courageous girl who fought till the very last minute for her dignity and her life. She is a true hero and symbolises the best in Indian youth and women... The nation will mourn the passing of this brave daughter of India" (The New Indian Express, December 29 2012). Mothers and daughters are subject to a national discourse of reverence towards femininity which upholds the heteronormative and patriarchal values that have emerged alongside Indian nationalism. The diversity of sexual experience in India is erased in favor of an idealization of the Indian family which demarcates non-heteronormative sexualities as non-Indian. The eruption of protests against sexual violence in India is an articulation of precisely this problem: that a woman who steps outside of her family's protective regulation is vulnerable to violation. The central female characters in Fire are metonyms for the collision between a view of Indian nationalism rooted to tradition, and the reality of India's growing economic power and ability to purchase and consume global culture. Mothers, failed mothers, and mothers to be, are the organizing force in the family and the film and reflects the collision between conservative Indian nationalism and the transnational reality of Indian life and culture.

(S)Mothering the Lesbian 
Visualizing the Lesbian in Contemporary India

In her paralysis the maternal figure in Fire, Biji comes to represent the overarching but increasingly redundant power of tradition in Indian society. Throughout the film she acts as a silent but astute observer of the family dynamics at work, the most taboo aspects of which are clearly on display in front of her at various times. Her ringing bell draws attention not only to her own needs, but signals her disapproval of the disintegrating family unit around her. Her silence in the film allows her to be idealized by her sons, but it also facilitates her sexual abuse by the family’s male servant, Mundu. As an archetypal Indian woman, she embodies a tense contradiction: she is a figure at once revered and abused. While Mundu is left to look after her, he masturbates to a pornographic film, switching to the famous television adaptation of the Mahabharta in time for Radha's appearance to check on her mother-in-law. Biji tries to signal her distress, but the scene is dominated by Mundu's narration of the scene of female selfsacrifice being played out on the screen. Mundu's sexuality manifests through his repressed desire for Radha and his frequent masturbation in front of the family matriarch. In this short scene, some of the central tensions of the film are made explicit. The family matriarch is powerless to articulate the sexual violations around her, and is in the process the subjection of violation herself.

Although Biji is powerless to act, she is nonetheless the witness to the contradictions and hypocrisies that run beneath the veneer of a traditional family unit. This is powerfully symbolised by the alternation between the pornographic tape and the Indian epic, the Mahabharta. Later in the film, Biji witnesses a playful scene between where Radha dresses in some of her husband's clothes and dances with Sita to a Bollywood song. The mimicry of a 
Visualizing the Lesbian in Contemporary India

heterosexual couple is presumably taken further than even a Bollywood film would depict and the camera cuts to Biji looking to the floor and a peeping Mundu pronouncing that there is, "too much electricity." The electricity prompted by drag and performance is foregrounded earlier in the film when a newly arrived Radha is left alone in her room. She pulls on her husband's clothes over her own, playfully enacting a masculine dominance before assuming her role as a dutiful woman in the house. Her own erotic play in front of the mirror illustrates the way in which desires erupt in the home through disguise and subterfuge.

\section{Transnational Sexualities}

The signifiers of Western sexuality are hyperbolized figures of licentiousness that fuel much of the trade to the video store. Traded alongside the food prepared by Radha and Sita, the epitome of traditional domestic labor for women is juxtaposed with the veiled circulation of sexually taboo material. The collision between the traditional and the transnational serves to doubly bind Radha: she must service the family but in addition to this, must sacrifice her intimacy with her husband who demands and yet abhors her subservience.

Jatin's love for Julie, a Chinese-Indian who has cultivated an American accent, represents an internalized self-hatred for what traditional Indian society represents. Julie is keen to go to Hong Kong as a route into the west, to escape the antediluvian culture around her. Jatin only marries Sita when Julie makes it clear that he is not the Western husband she would hope for. While his marriage to a traditional Indian woman carries on at home, his barely veiled relationship with 
Visualizing the Lesbian in Contemporary India

Julie continues. As Sita realises this, it becomes clear that her own chances and rights to be desired and loved by her husband are null and void. She is offered a child by Jatin as a way to keep her occupied. In the meantime, Ashok's worship of his guru and his disavowal of sex becomes a sexual and emotional rejection for Radha, whose sexual purpose is reduced to lying next to Ashok while he tests his resilience against her. Both Jatin and Ashok displace their sexual energies away from the home, seeing their wives in the context of motherhood and duty. The sexual tension between Radha and Sita emerges in parallel with Jatin and Ashok's refusal to allow them to feel sexually desired. The basis for reading the sexual tension as a kind of aberration in the eyes of Hindu nationalism becomes clear: if there is a lesbian context in this film, perhaps it partially emerges as a result of the fracture in the primary heternormative units. However alternative readings are possible, and indeed invited by the film itself.

\section{Illegible Kinships}

The narrative of Fire is framed in terms of marriage, family and domestic life and the religious rituals and traditions that surround these. As Gopinath states, within the film female same-sex sexuality appears "at the interstices of rigidly heterosexual structures, detailing the ways in which desire is routed and rooted within the space of the middle-class home" (Gopinath 2005: 153). The film opens with an idealized scene in which we encounter Radha as a child sitting in a meadow with her parents, while her mother encourages her to imagine the ocean with the words "What you can't see you can see, you just have to see without looking." The film then jumps forward in time to the events following Sita's marriage to Jatin, and the audience is encouraged to make the connection between the invitation to "see without looking" and the story of female 
Visualizing the Lesbian in Contemporary India

same-sex desire that is about to unfold. In contrast to this nostalgic representation of Radha's childhood, the domestic life of her adulthood is far from perfect. For Ashok, his celibacy and self-testing helps him "come closer to the universal truth" but it is also a means by which Ashok can punish his wife for her infertility. When Radha asks "But how does it help me?", Ashok's response is simply "By helping me you are doing your duty as my wife." Ashok not only spends a considerable amount of time with his guru, but also supports him financially, and the relationship is implicitly homoerotic. In a key scene before the exposure of the women's affair, Ashok and his guru are watching a theatrical performance of the Ramayana and Ashok massages his guru's foot; an act mirroring an earlier scene in which Sita massages Radha's foot in full view of an uncomfortable Ashok.

Celibacy or self-restraint and intense male relationships are only two of a range of expressions of sexuality and sexual power and control within this joint family structure. As we have seen, Jatin's real love is Julie, who has refused to marry him, while the family servant, Mundu, subjects the aged Biji (who is often entrusted into his care) to sexual abuse by secretly forcing her to watch him masturbate in front of pornographic films. In marked contrast, the desire of the sisters-in-law is not unreciprocated, exploitative or abusive. Instead, within the closed domestic space of this household, Radha and Sita's relationship offers a counterpoint to reproductive heteronormativity. Judith Butler, in Undoing Gender discusses the way "efforts to establish bonds of kinship that are not based on a marriage tie become nearly illegible and unviable when marriage sets the terms for kinship, and kinship itself is collapsed into "family'" (Butler 2004: 5). Within an Anglo-American context, queer theorists advocate alternative kinships and chosen 
Visualizing the Lesbian in Contemporary India

families, or, in the case of Judith Halberstam, propose that we forget families altogether (Halberstam 2007). Fire, in its positive representation of Radha and Sita's relationship, works within a traditional family system. Indeed, while the affair remains within the confines of the domestic space, under the all-seeing eyes of Biji, it can flourish. In other words, so long as the life that Radha and Sita choose remains invisible or illegible to all except Biji, it is, in Butler's terms, "liveable" (Butler 2004: 1). Arguably, Radha's and Sita's lives, confined though they are to a narrow domestic sphere, are more liveable than those of their husbands, who despite their greater mobility and freedom are thwarted in their desire for children or for a marriage based on love, respectively. Ultimately, Biji and Ashok together leave Radha to what seems like an almost certain death, which occurrs only after the sexual relationship of the women has been exposed and they have agreed to flee their home, and thus Biji herself. It is at this moment of exposure or legibility that the lives of Radha and Sita seemingly become unliveable.

\section{Sacramentality and Desire}

While Fire was condemned as anti-Hindu, anti-tradition, and anti-family (see Patel 2002), and much of the controversy surrounding the film — or rather, the controversy on which Western critics have chosen to focus_- has centered on the representation of lesbianism in the film which is perceived as a Western imposition on Indian culture, the complex representation of religion and more specifically, the representation of the sacred within the film has been seemingly overlooked. Indeed the name of film, Fire, alludes both to burning sensual desire and to the sacred. The Vedic deity Agni or Fire is the receiver of sacrifices and the intermediary with the gods. What happens when we look "through rather than at" the sacred and the sacramental 
Visualizing the Lesbian in Contemporary India

within the film (the formulation here, used in relation to cross-dressing, is found in Garber 1992, 187)?

In making sense of the film Fire, and of what it attempts to accomplish, Elizabeth Freeman's essay, "Sacramentality and the Lesbian Premodern" proves particularly useful. Freeman, who is influenced by Bruce Holsinger's work on medievalism and postmodern theory (Holsinger 2005), focuses specifically on the Christian sacrament of the Eucharist when she argues that theorists of the contemporary could learn from a greater understanding, not of abstract belief systems, but of devotional practices and embodied rites. Freeman states:

I'm taken with the idea of treating texts the way sacraments are treated: take, eat, this is my body, this is my text. Breaking them, taking them, eating them, drinking them, as if they were body and blood capable not only of transforming our own minds, but also our individual bodies, and of manifesting not expertise (the secular humanist version of salvation) but communitas across previously divided spaces and times. (Freeman, 2011: 182)

Although Freeman is specifically talking here about the Catholic mass and Protestant communion, the sacred and the sacramental are not Christian preserves. The idea that sacraments bring about inner change and draw together communities are common to many religions, including Hinduism, in which the Samskaras mark the major life stages from pregnancy and childbirth through marriage to death. 
Visualizing the Lesbian in Contemporary India

The film Fire demonstrates a sacramental longing, as Freeman puts it, "to risk an enchanted, superstitious, mystical, even religious outlook in order to know differently ... to risk fantasy, self-indulgence, vulgarity, and eroticism as modes of cognitive apprehension” (Freeman 2001: 184). The film's dramatic, or melodramatic, ending encapsulates this desire. The two sisters-inlaw in the film are given religiously loaded names. According to Hindu tradition Radha is the lover of Krishna, and although she is married to another man, her relationship with Krishna is seen as the embodiment of passion and devotion. In the Sanskrit epic devotional text, the Ramayana, Sita, the wife of King Ram or Rama, an important incarnation of Vishnu, represents the ideal wife. Sita chooses to follow her husband into exile, but is kidnapped by a demon king, and on being reunited with her husband is consigned to a fire to test her chastity. She survives her agni pariksha unharmed. The conclusion of the film Fire reverses the narratives, with the elder sister-in-law Radha surviving a blaze in her kitchen (from which Ashok walks away carrying a compliant Biji) and fleeing her home to join Sita, who is waiting for her in the sacred space of the Hindu temple. The role of Biji in this narrative is ambiguous: in proving the purity of Radha's love for Sita, she plays the role of Ram, but conversely she is also willing to leave Radha to die.

As Gopinath notes "The image of Sita emerging unscathed from her agni pariksha, or trial by fire, is the inescapable motif around which the women's lives revolve throughout the film ... the background noise in their daily lives is the popular serialization of the Ramayana, which plays incessantly on the television" (Gopinath 2005: 141). The devotional narrative seems to be at the heart of the domestic space in which Radha and Sita share. Indeed Radha states that Biji, who is 
Visualizing the Lesbian in Contemporary India

unable to speak and communicates by ringing a bell, takes solace from these productions. Yet, both Radha and Sita find themselves isolated from spiritual fulfilment. While, as noted above, Radha's husband Ashok finds some personal satisfaction in his relationship with his guru, Radha is expected to serve Ashok's needs by neglecting her own. Radha and Sita discuss the importance of religious rituals when the two women celebrate Karva Chauth, a festival in which married women fast for a day in order to ensure that their husbands enjoy a long life. The fast is broken at moonrise, when the husband offers his wife water and food. Sita is disparaging about her own decision to observe the fast, stating "Somebody just has to press my button, this button marked 'tradition', and I start responding like a trained monkey." Nevertheless despite these reservations she goes ahead with it. In the evening, however, Sita's husband Jatin does not return to the home, and it is Radha who takes his place, holding the glass of water from which Sita drinks. At one point in the film Sita states, "I'm sick of all this devotion. We can find choices"; but as the breaking of the fast episode illustrates, ultimately the choices the women find are routed through the devotional and the sacramental.

Sita's famous comment, made in English, that she and Radha have "no word" in their language to describe their love for one another, is then mitigated by the importance of non-verbal communication within the film. Radha's response that "Seeing is less complicated" articulates one of the key messages of the film: a visual representation is a more powerful intervention in the debate about the viability and validity of relationships between women because it circumvents current controversies about the imposition of Western cultural and social constructs, identity politics, and labels. At the same time, the film emphasizes the importance of the aural as 
Visualizing the Lesbian in Contemporary India

well as the visual. Bells, and the music of bells, are a central motif in Fire. As already mentioned Biji uses the bell to communicate, but this has an additional religious symbolism. Within Hinduism, the bell can be used to ward off evil spirits. At the same time, the bell or Ghanta is auspicious: it is rung in the temple in puja, as a summons to the deities. The music of the bell accompanies key love scenes between Radha and Sita, and the closing scene when they are reunited within the sacred space of the temple.

\section{Recovering A Lesbian Presence}

What does the film achieve by evoking religious narratives and rituals? Monica Bachmann, in her essay "After the Fire," notes that the defenders of the film argue that narratives of female same-sex love have a long history in Indian culture (Bachmann 2002: 239). Vanita, while rejecting the term "lesbian" has recently offered a reading of a Hindu narrative concerning the union of two women, a union from which Ram is ultimately descended. The narrative in question is found in some lesser-known Vaishnava, texts devoted to Vishnu from Bengal from the fourteenth century and later. In two of these versions, both in the Bengali language, the women are represented as experiencing "extreme love" or as "burning with desire" (Vanita 2011: 121). The second of these versions names the women as Chandra and Mala and states: "Chandravati played the man and Mala the woman / The two women dallied and made love". As in Fire, these early texts enact female same-sex desire within a patriarchal domestic (if divine) context. By creating discordance between Radha and Sita and their religious namesakes, and by having the women play the roles ascribed to male deities, Fire finds, or recovers "a lesbian presence"-to once again draw on Freeman's terminology (Freeman 2011: 182) —in sacred Hindu texts. In 
Visualizing the Lesbian in Contemporary India

inviting its audience to view the performance by women of rituals that are normally reserved for married couples, in asking its audience to reinterpret religious narratives by placing female protagonists in male roles and by drawing its audience into the sacred space of the Hindu temple in the closing scene, the film also invites the audience to take part in a sacramental process of transformation, not simply as individuals, but as a community.

\section{Conclusion}

Fire rests at an intersection between a series of competing discourses on diasporic identity, sexuality, nationalism, religion, modernity and globalization. It inhabits an overdetermined site, which is loaded with ambiguity and difficulty. This is most notably exemplified in the inability of the heroines to articulate through language their position and relationship in this intricate network, even as they succeed in articulating it through religious sacraments and symbols. Fire deliberately avoids engaging with the term "lesbian" at the same time as it explores a relationship which, as the responses to the film illustrate, is identifiable as lesbian in Indian as well as Western culture. Fire does not however represent this relationship in Westernized terms. Rather, it uses religious symbols and narratives in order to examine productively the question of whether lesbianism within contemporary Indian culture is liveable or even possible.

Fire's conclusion offers a kind of promise: Sita and Radha escape the family home after an attempt to immolate Radha by her husband. The end of the film, although tragic in many aspects, signals a kind of optimism and possibility, but one which is ultimately evacuated from the home. 
Visualizing the Lesbian in Contemporary India

By representing the mythological lives of Radha and Sita alongside the conflation of mother-asnation in the context of contemporary urban Indian life, the film plays with the various ways in which the national and religious discourses which structure femininity play a part in an Indian envisioning of lesbian desire. The Hindu temple at the conclusion of the film becomes the most positive site by providing a temporary shelter for the women and becoming the site at which their desire can be articulated independently from the home.

While the conclusion to the film seems cautiously optimistic, reviewing the film in the light of the Delhi rape case of December 2012 and subsequent events, we are reminded that even today, women's independence is severely constrained, and that crimes against women are not only widespread, but widely condoned. In 1996, Thadani wrote about the dangers for lesbians of travelling on public transport (Thadani, 114). In 2013 the dangers for all women are evident. Reviewing the film in 2013 , the conclusion seems to represent a fantasy of the future, rather than a viable reality in the present day. Within Fire, the circumnavigation of heteronormative power and desire is certainly queer, but more importantly, its labelling as "lesbian" subsequent to its release in India, opened up an important public forum for a debate about female desire and independence. To return to CALERI's declaration: “We did consider that the word 'lesbian' as Western and elitist, but we also felt that, in a campaign which is to take information to the people, we need to organize around a word whose meaning is unmistakable and direct" (quoted by Dave 2012, 157). The framework of this article belongs to the "Western" and "elitist" academy and is certainly not an attempt to offer a conclusive argument about the use of the term "lesbian" to label Sita and Radha's relationship. Yet as the Caleri statement and the work of 
Visualizing the Lesbian in Contemporary India

critics such as Dave (2012) makes clear, at a moment of convergence between rapid economic and cultural globalization and international interventions in Indian LGBTQ, there is critical value in a lesbian political, cultural and social space. Fire's interpellation into lesbian politics is facilitated by the strong emphasis on a female-centred desire that is not defined by motherhood, that cannot be contained, and that demands to be seen.

\section{Works Cited}

Arondekar, Anjali (2005). "Without a Trace: Sexuality and the Colonial Archive", Journal of the History of Sexuality 14.1/2: 10-27.

Bacchetta, Paola.(1999). "When the (Hindu) Nation Exiles Its Queer," Social Text 61, 141-166.

Bachmann, Monica (2002). “After the Fire” in Ruth Vanita (ed), Queering India: Same-Sex Love and Eroticism in Indian Culture and Society. New York and Lonn: Routledge, 234-244.

Barron, Alexandra Lynne (2008). "Fire’s Queer Anti-Communalism”, Meridians: Feminism, Race, Transnationalism 8 (2), 64-93.

Butler, Judith (2004). Undoing Gender. New York and London: Routledge.

Dave, Naisargi N (2012). Queer Activism in India: A Story in the Anthropology of Ethics. Durham: Duke University Press.

Dave, Naisargi N (2011) "Indian and Lesbian and What Came Next: Affect, Commensuration, and Queer Emergences”, American Ethnologist 38 (4), 650-665. 
Visualizing the Lesbian in Contemporary India

Dave, Naisargi N (2010) “To Render Real the Imagined: An Ethnographic History of Lesbian Community in India.”, Signs: Journal of Women in Culture and Society 35 (3), 595-619.

Desai, Jigna. (2004). Beyond Bollywood: The Cultural Politics of South Asian Diasporic Film. New York and London: Routledge.

Ebert, Roger (1997). "Fire". Retrieved from http://www.rogerebert.com/reviews/fire-1997. Dec 10, 2013.

Fire.(1996). Dir. Deepa Mehta, India/Canada, Zeitgeist Films.

Freeman, Elizabeth (2011). "Sacramentality and the Lesbian Premodern”. In Noreen Giffney, Michelle M. Sauer and Diane Watt (eds), The Lesbian Premodern. New York: Palgrave, pp.179186.

Garber, Marjorie (1992). Vested Interests: Cross-dressing and Cultural Anxiety (New York and London: Routledge).

Gopinath, Gayatri (2005). Impossible Desires: Queer Diasporas and South Asian Cultures. Durham, NC: Duke University Press.

Halberstam, Judith “Jack” (2007). "Forgetting Family: Queer Alternatives to Oedipal Relations". In George E. Heggerty and Molly McGarry (eds), A Companion to Lesbian, Gay, Bisexual, Transgender and Queer Studies. Oxford: Blackwells, 315-324.

Holsinger, Bruce (2005). The Premodern Condition: Medievalism and the Making of Theory. Chicago: University of Chicago Press. 
Visualizing the Lesbian in Contemporary India

The New India Express (2012). “President, PM mourn gang-rape victim's death”. Retrieved from http://www.newindianexpress.com/nation/article1399403.ece, Dec 10, 2013.

Mother India. 1957 Dir. Mehboob Khan. Mehboob Productions, India.

Patel, Geeta. 2002. “On Fire: Sexuality and Its Incitements.” In Ruth Vanita (ed.), Queering India: Same-Sex Love and Eroticism in Indian Culture and Society, New York: Routledge, 22233.

Pink Pages (2012). “A Photographic History of the Indian Gay Rights Movement”. Retrieved from http://pink-pages.co.in/general/a-photographic-history-of-the-indian-gay-rightsmovement/nggallery/image/gays-hit-the-streets/, Dec 10, 2013.

Ramaswamy, Sumathi (2010). The Goddess and the Nation: Mapping Mother India. Durham: Duke University Press.

Rupp, Leila (2011). Sapphistries : A Global History of Love Between Women. New York: NYU Press.

Thadani, Giti (1996). Sakhiyani: Lesbian Desire in Ancient and Modern India. London: Cassell. Vanita, Ruth (ed) (2002). Queering India: Same-Sex Love and Eroticism in Indian Culture and Society. New York and London: Routledge.

Vanita, Ruth (2011). "Naming Love: The God Kama, the Goddess Ganga, and the Child of Two Women.” In Noreen Giffney, Michelle M. Sauer and Diane Watt (eds), The Lesbian Premodern. New York: Palgrave. 119-130. 
Visualizing the Lesbian in Contemporary India 